\title{
Angiotensin II type 1 receptor (A1166C) gene polymorphism and Essential hypertension in Egypt
}

\author{
Marium M. Shamaa* \\ Department of Pharmacology and Toxicology, Faculty of Pharmacy and Drug Manufacturing, Pharos University in Alexandria, Egypt
}

\begin{abstract}
The pathogenesis of essential hypertension $(\mathrm{EH})$ is affected by genetic and environmental factors. Mutations in hypertension-related genes can affect blood pressure (BP) via alteration of salt and water reabsorption by the nephron. The genes of the renin-angiotensin system (RAS) have been extensively studied because of the well documented role of this system in the control of BP. It has been previously shown that Angiotensin II type 1 receptor (ATR1) gene polymorphism could be associated with increased risk of EH. So, in the current study, we evaluated the frequency of ATR1 (A1166C) polymorphism in relation to EH in a group of Egyptian population. The study population included 83 hypertensive patients and 60 age and sex matched healthy control subjects. Restriction fragment length polymorphism - Polymerase chain reaction (RFLP - PCR) was used for the analysis of A1166C polymorphism of ATR1 genes in peripheral blood samples of all patients and controls. The results revealed that there was a positive risk of developing EH when having the T allele whether in homozygous or heterozygous state. From this work, it was concluded that there was an association between ATR1 (A1166C) gene polymorphism and the risk of developing EH.
\end{abstract}

\section{Introduction}

Essential hypertension is a major risk factor for several cardiovascular diseases. It is a complex trait resulting from the interactions of multiple genetic and environmental factors. Moreover, not only genetic but also epigenetic inheritance plays a significant role. One can speculate that hypertension develops as a consequence of "errors" in the well-coordinated regulatory systems of blood pressure [1]. This common disease-common variant concept suggests that the genetic heterogeneity underlying hypertension susceptibility could be relatively small. Therefore, it makes sense that variation in genes related to hypertension should be studied [2]. In recent years, the research is directed towards analyzes of the disease on genetic level and explanation of the genetic bases of this disorder. Development of powerful and sensitive molecular techniques has resulted in widespread endeavors to dissect the genetic factors and their molecular defects accounting for hypertension in various populations. Today, the state of the art approach toward the diagnosis of primary hypertension involves analysis of the genetic bases for the disorder [3].

The renin-angiotensin system (RAS) is a group of related hormones that act together to regulate $\mathrm{BP}$ by maintaining vascular tone and the balance of water and sodium. Angiotensin II type 1 receptor (ATR1) is among the components that are involved in the activation/effector cascade of the RAS. Ang II is a potent vasoconstrictor that exerts most of its known cellular actions through the Ang II type 1 receptor (AT1). The Ang II AT1 receptor is a membrane bound G protein-coupled receptor that mediates the vasoconstrictive effects of Ang II [4,5]. Although many polymorphisms of the ATR1 gene have been identified, the (A1166C) polymorphism has been the most extensively studied. The (A1166C) polymorphism is in a non coding region of the gene, and therefore the amino-acid sequence of the receptor is not altered. In theory, associations with ACE genotype may be due to functional variants in nearby loci, and/or related genetic polymorphism [6].

The ATR1 gene (A1166C) polymorphism has been shown to be associated with oxidative stress in heart failure patients [7]. It has been also shown to interrupt the ability of microRNA-155 to attenuate translation, resulting in augmented ATR1 expression [8]. This suggests a potential functional mechanism by which the 3'UTR A1166C polymorphism can lead to increased oxidative stress and the development of cardiovascular diseases. Taken together, these findings are interpreted to support the hypothesis that ATR1 (A1166C) polymorphism is related to augmented angiotensin II activity and important clinical end-points, including $\mathrm{EH}$ and cardiovascular disease [9]. Genetic polymorphisms in components of the RAS including ATR1 (A1166C) are suggested to be associated with the pathogenesis of EH. However, obtained results are still debated [4].

The analysis of RAS related genetic polymorphism of patients having $\mathrm{EH}$ has been carried out in Egyptian population on a limited scale. So, this study aimed to determine the association of genetic polymorphisms of the Angiotensin II type 1 receptor (A1166C) gene polymorphism with $\mathrm{EH}$ in a cohort of genetically homogenous $\mathrm{EH}$ patients and normotensive controls (case - control study).

\section{Materials and methods}

The current study included $83 \mathrm{EH}$ patients (55 male, 28 female) with mean age of $53.5 \pm 7.4$ years old. Also 60 healthy subjects ( 32 male, 28 female) matching in age and sex ( $51.3 \pm 8.8$ years old) were included as control group. The patients were selected from the outpatient clinic of the Cardiology Department, General Alexandria University

Correspondence to: Marium M. Shamaa, Assistant Lecturer, Department of Pharmacology and Toxicology, Faculty of Pharmacy and Drug Manufacturing, Pharos University in Alexandria, Egypt; E-mail: marium_ph2007@yahoo.com

Key words: essential hypertension, ATR1(A1166C) polymorphism, Angiotensin II type 1 receptor gene

Received: April 20, 2015; Accepted: May 25, 2015; Published: May 28, 2015 
Hospital during the period between 2009 and 2010. A written consent was obtained from all subjects accepting to participate in the study for both the clinical part and the genetic study. All subjects under study were subjected to thorough history taking and clinical examination with special emphasis on BP and BMI. Peripheral blood samples were collected from all subjects and routine investigations were done including FBS, lipid profile (total cholesterol, LDL - ch, HDL - ch and triglycerides) and renal function tests (serum urea and creatinine).

Essential hypertension was diagnosed in individuals with a systolic blood pressure (SBP) $>140 \mathrm{mmHg}$ and/or a diastolic blood pressure (DBP) $>90 \mathrm{mmHg}$ or in those currently receiving anti-hypertensive therapy. Secondary forms of hypertension were excluded based on clinical history and laboratory investigations. The normotensive controls were healthy individuals with a negative history of hypertension and with a SBP $<140 \mathrm{mmHg}$ and $\mathrm{DBP}<90 \mathrm{mmHg}$ measured on three separate occasions, also all study subjects were non diabetic with normal renal functions.

\section{Genotyping}

DNA samples were isolated from peripheral blood lymphocytes by the standard phenol extraction method (Sambrook et al., 1989). The ATR1 (A1166C) polymorphisms was detected by RFLP PCR using the following primers: 5'- GCA GCA CTT CAC TAC CAA ATG GGC - 3' as forward primer and 5' CAG GAC AAA AGC AGG CTA GGG AGA - 3' as reverse primer. Amplification resulted in a 255-bp product. Then the PCR product was digested with the restriction enzyme Bacillus species (BsuRI). Electrophoresis on a $3 \%(\mathrm{w} / \mathrm{v})$ agarose gel containing $0.5 \mu \mathrm{g} / \mathrm{ml}$ ethidium bromide (Sigma-Aldrich, St. Louis, USA) and UV transillumination were used for analysis.

Statistical Analysis was carried out using SPSS version 15.0 software and the following tests were used for data analysis: Chi squared $\left(\chi^{2}\right)$ test, Monte Carlo Probability (MCP) and Fisher's Exact Probability (FEP) were used for analysis of categorical data, T-test was used for comparison between means, Odds ratio (OR) was used for the measurement of association.

\section{Results}

The results showed that there was a highly statistically significant difference $(\mathrm{P}<0.001$, and $\mathrm{P}<0.001)$ in both the systolic $\mathrm{BP}(145.28 \pm 7.0$ $\mathrm{mmHg})$ and the mean diastolic $\mathrm{BP}(91.2 \pm 2.15 \mathrm{mmHg})$ of hypertensive patients when compared to their corresponding values $(117.33 \pm 4.27$ $\mathrm{mmHg}$ and $79.17 \pm 3.46 \mathrm{mmHg}$ ), respectively of normotensive subjects (control group).

Genotyping of ATR1(A1166C) polymorphism, detected after PCR amplification and BsuRI digestion, yielded two bands of 231 and $24 \mathrm{bp}$ in the presence of the restriction site (C allele) and only one band of 255 $\mathrm{bp}$ in the absence of the restriction site (A allele). Heterozygotes (AC) produce two bands of 255 and $231 \mathrm{bp}$ [10]. (Figure 1 and 2).

The results revealed that the frequency of the AC genotype was significantly $\left(\chi^{2}=10.612^{\star}, p=0.005\right)$ increased in hypertensive patients. Furthermore, there was a positive risk of developing EH when having the $\mathrm{CC}$ and $\mathrm{AC}$ genotypes and the results were highly statistically significant $(\mathrm{OR}=2.89, \mathrm{p}=0.022)$ (Table 1 and 3$)$.

The frequency of $C$ allele was significantly $\left(\chi^{2}=12.930^{*}, p<0.001\right)$ increased in hypertensive patients. Furthermore, there was a positive risk of developing $\mathrm{EH}$ when having the $\mathrm{C}$ allele whether in homozygous or heterozygous state and the results were highly statistically significant $(\mathrm{OR}=4.313, \mathrm{p}<0.001)($ Tables 2 and 4$)$.

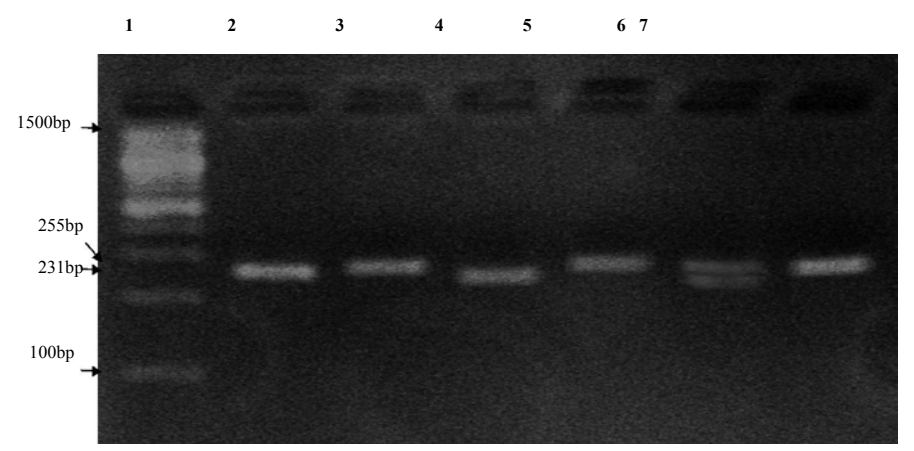

Figure 1. Agarose gel (3\%) electrophoresis for RFLP digested PCR products. Lane 1: 100bp base pair marker. Lane 2: undigested PCR product of a patient with AA genotype (255 bp) (Positive Control). Lane $(3,5,7)$ : unrestricted fragments of PCR products of patients with AA genotype $(255 \mathrm{bp})$. Lane 6 : restricted PCR product of a patient with AC genotype (255, $231 \mathrm{bp})$. Lane 4: restricted PCR product of a patient with CC genotype (231 bp).

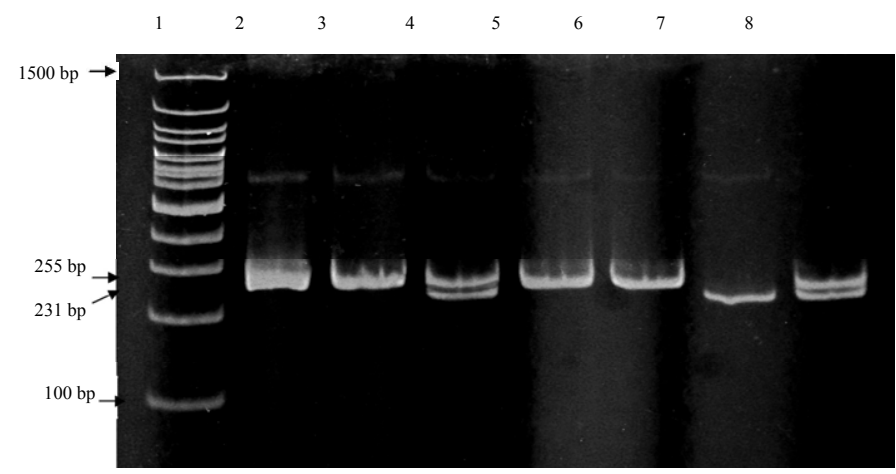

Figure 2. Polyacrylamide gel electrophoresis of ATR1 (A1166C) polymorphism bands after digestion by Bsu RI, lane 1: bp marker (100 bp). Lane 2, 3, 5 and 6: AA homozygote. Lane 7: CC homozygote and lane $(4,8)$ : AC heterozygote.

Table 1. The frequency of ATR1 (A1166C) polymorphic genotypes in normotensive subjects (control) and hypertensive patients.

\begin{tabular}{|c|c|c|c|c|c|}
\hline & \multicolumn{2}{|c|}{ Control $(n=60)$} & \multicolumn{2}{|c|}{ Patients $(n=83)$} & \multirow[t]{2}{*}{$\chi^{2}(\mathrm{p})$} \\
\hline & No. & $\%$ & No. & $\%$ & \\
\hline ATR1 genotypes & & & & & \\
\hline AA & 53 & 88.3 & 55 & 66.3 & $9.175 *(0.002)$ \\
\hline $\mathrm{AC}$ & 7 & 11.7 & 21 & 25.3 & $4.111 *(0.043)$ \\
\hline $\mathrm{CC}$ & 0 & 0.0 & 7 & 8.4 & $\mathrm{FEp}=0.022^{*}$ \\
\hline $2(p)$ & \multicolumn{4}{|c|}{$10.612\left(0.005^{*}\right)$} & \\
\hline
\end{tabular}

$\chi^{2}$ : Chi square test

*: Statistically significant at $\mathrm{p} \leq 0.05$ FEp: $\mathrm{p}$ value for Fisher Exact test

Table 2. The frequency of ATR1 A and C alleles in normotensive subjects (control) and hypertensive patients.

\begin{tabular}{|c|c|c|c|c|c|}
\hline & \multicolumn{2}{|c|}{ Control $(n=60)$} & \multicolumn{2}{|c|}{ Patients $(n=83)$} & \multirow[t]{2}{*}{$\chi^{2}(\mathrm{p})$} \\
\hline & Freq. & $\%$ & Freq. & $\%$ & \\
\hline ATR1 alleles & 113 & 94.16 & & & \\
\hline A & 7 & 5.83 & 131 & 78.92 & \\
\hline $\mathrm{C}$ & & & 35 & 21.08 & $12.930 *(<0.001)$ \\
\hline
\end{tabular}

$\chi 2$ : Chi square test

$*$ : Statistically significant at $\mathrm{p} \leq 0.05$

\section{Discussion}

Cardiovascular diseases are rapidly emerging as a major health concern in most developing countries, including Egypt, and hypertension is one of the major preventable causes of morbidity and mortality from cardiovascular disease. Very recently, Arafa and Ez- 
Table 3. The risk of having ATR1 (A1166C) polymorphism in relation to essential hypertension.

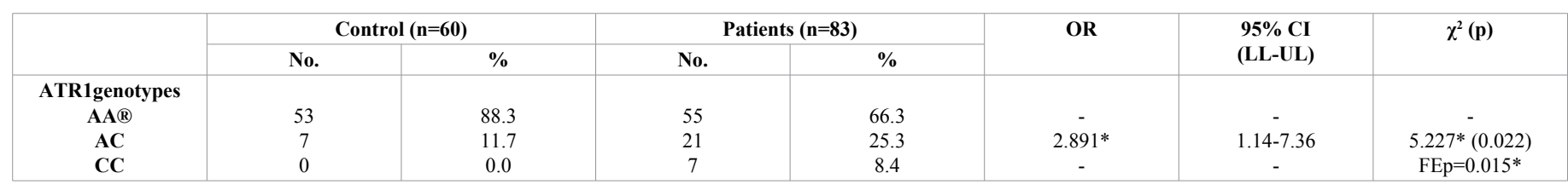

$\chi 2$ : Chi square test $\quad *$ : Statistically significant at $\mathrm{p} \leq 0.05$ FEp: $\mathrm{p}$ value for Fisher Exact test

Table 4. The risk of having $\mathrm{C}$ allele in relation to essential hypertension.

\begin{tabular}{|c|c|c|c|c|c|c|c|}
\hline & \multicolumn{2}{|c|}{ Control $(n=60)$} & \multicolumn{2}{|c|}{ Patients $(n=83)$} & \multirow[t]{2}{*}{ OR } & \multirow{2}{*}{$\begin{array}{l}95 \% \text { CI } \\
\text { (LL-UL) }\end{array}$} & \multirow[t]{2}{*}{$\chi^{2}(\mathrm{p})$} \\
\hline & No. & $\%$ & No. & $\%$ & & & \\
\hline $\begin{array}{c}\text { ATR1genotypes } \\
\text { A® } \\
\text { C }\end{array}$ & $\begin{array}{c}113 \\
7\end{array}$ & $\begin{array}{c}94.16 \\
5.83\end{array}$ & $\begin{array}{c}131 \\
35\end{array}$ & $\begin{array}{l}78.92 \\
21.08\end{array}$ & $\begin{array}{c}- \\
4.313^{*}\end{array}$ & $\stackrel{-}{-}$ & $12.930 *(<0.001)$ \\
\hline
\end{tabular}

$\chi 2$ : Chi square test $\quad *$ : Statistically significant at $\mathrm{p} \leq 0.05$

elarab (2011) [11] calculated the prevalence of prehypertension and hypertension based on the data of 6671 individuals from the EDHS 2008. The prevalence of prehypertension and hypertension in Egypt were $57.2 \%$ and $17.6 \%$, respectively. Only $25.2 \%$ of the population had normal BP levels of $<120 / 80 \mathrm{mmHg}$.

The analysis of ATR1 (A1166C) gene polymorphism of patients having EH has been carried out in Egyptian population on a limited scale. The potential role of the ATR1 gene in predisposition to hypertension is controversial. Since Bonnardeaux et al., (1994) [12] previously reported higher prevalence of the C1166 allele among hypertensive than among normotensive subjects, a large number of studies have explored the relationship between ATR1 gene polymorphism and HT. In the current study, the percentage of the AC and CC genotypes were significantly more frequent in hypertensive patients than in the control group $(\mathrm{p}<0.001)$. Moreover, the $\mathrm{C}$ allele was the risk allele for hypertension where the study subjects carrying $\mathrm{C}$ allele were at more than seven-fold higher risk for hypertension $(\mathrm{OR}=4.313, \mathrm{p}<0.001)$. The results of this study were in accordance with studies that were conducted in Budapest, Hungary (Szombathy et al., (1998) [13]), in French women (Tiret et al., (1998) [14]), in Serbia (Stankovic et al., (2003) [15]), in Japanese subjects (Kobashi et al., (2004) [16]), Han Chinese (Niu et al., (2009) [17]) and in Tunisian population (Mehri et al., (2011) [18]). On the contrary, there was no significant association between the A1166C polymorphism and hypertension in a German population (Schmidt et al., (1997) [19], Morisawa et al., (2001) [20]), on non-Caucasian populations (Takami et al., (1998) [21]) and in Hispanics population (Bautista et al., (2008) [22]).

\section{Conclusion and recommendations}

The present study provided an additional observation concerning ATR1 (A1166C) polymorphic genotypes in a sample of Egyptian patients with EH. From this study it was concluded that:

1. The frequency of $\mathrm{C}$ allele was higher in hypertensive patients (22\%) as compared to control subjects (6\%). On the contrary, the A allele was less frequent in hypertensive patients (79\%) as compared to control subjects (94\%).

2. Homozygousity for the ATR1 C allele was a risk factor for EH. Moreover, the presence of ATR1 C allele, whether in homozygous or heterozygous state, was a risk factor for $\mathrm{EH}$.

It is recommended that:
1. Future studies should investigate the influence of genetic polymorphisms of the ATR1 (A1166C) polymorphic genotypes on response to anti-hypertensive therapy.

2. Future studies should evaluate the association of the ATR1 (A1166C) polymorphic genotypes in other human diseases affected by alterations in the RAS.

\section{References}

1. Kunes J, Zicha J (2009) The interaction of genetic and environmental factors in the etiology of hypertension. Physiol Res 58 Suppl 2: S33-41. [Crossref]

2. Balam-Ortiz E, Esquivel-Villarreal A, Alfaro-Ruiz L, Carrillo K, Elizalde A, et al. (2011) Variants and haplotypes in angiotensinogen gene are associated with plasmatic angiotensinogen level in Mexican population. Am J Med Sci 342: 205-211. [Crossref]

3. Elzanaty F, Way A (2009) Egypt Demographic and Health Survey 2008. Recommended citation. Ministry of Health El-Zanaty and Associates and Macro International. Chapter 17: Adult Health Issues 11: 228-235.

4. Unger T, Paulis L, Sica DA (2011) Therapeutic perspectives in hypertension: novel means for renin - angiotensin - aldosterone system modulation and emerging devicebased approaches. Eur Heart J 32: 2739-2747. [Crossref]

5. Santos RA, Ferreira AJ, Simões E Silva AC (2008) Recent advances in the angiotensinconverting enzyme 2-angiotensin(1-7)-Mas axis. Exp Physiol 93: 519-527. [Crossref]

6. Puthucheary Z, Skipworth JR, Rawal J, Loosemore M, Van Someren K, et al. (2011) The ACE gene and human performance: 12 years on. Sports Med 41: 433-448. [Crossref]

7. Cameron VA, Mocatta TJ, Pilbrow AP, Frampton CM, Troughton RW, et al. (2006) Angiotensin type-1 receptor A1166C gene polymorphism correlates with oxidative stress levels in human heart failure. Hypertension 47: 1155-1161. [Crossref]

8. Martin MM, Buckenberger JA, Jiang J, Malana GE, Nuovo GJ, et al. (2007) The human angiotensin II type 1 receptor $+1166 \mathrm{~A} / \mathrm{C}$ polymorphism attenuates microRNA-155 binding. J Biol Chem 282: 24262-24269. [Crossref]

9. Poirier O, Georges JL, Ricard S, Arveiler D, Ruidavets JB, et al. (1998) New polymorphisms of the angiotensin II type 1 receptor gene and their associations with myocardial infarction and blood pressure: the ECTIM study. Etude Cas-Témoin de l'Infarctus du Myocarde. J Hypertens 16: 1443-1447. [Crossref]

10. Buraczynska M, Ksiazek P, Drop A, Zaluska W, Spasiewicz D, et al. (2006) Genetic polymorphisms of the renin-angiotensin system in end-stage renal disease. Nephrol Dial Transplant 21: 979-983. [Crossref]

11. Arafa NA, Ez-elarab HS (2011) Epidemiology of prehypertension and hypertension among Egyptian adults. Egyp J Сотти Med 29: 1-18.

12. Bonnardeaux A, Davies E, Jeunemaitre X, Féry I, Charru A, et al. (1994) Angiotensin II type 1 receptor gene polymorphisms in human essential hypertension. Hypertension 24: 63-69. [Crossref]

13. Szombathy T, Szalai C, Katalin B, Palicz T, Romics L, et al. (1998) Association of angiotensin II type 1 receptor polymorphism with resistant essential hypertension. Clin Chim Acta 269: 91-100. [Crossref] 
14. Tiret L, Blanc H, Ruidavets JB, Arveiler D, Luc G, et al. (1998) Gene polymorphisms of the renin-angiotensin system in relation to hypertension and parental history of myocardial infarction and stroke: the PEGASE study. Projet d'Etude des Gènes de l'Hypertension Artérielle Sévère à modérée Essentielle. J Hypertens 16: 37-44. [Crossref]

15. Stankovic A, Zivkovic M, Glisic S, Alavantic D (2003) Angiotensin II type 1 recepto gene polymorphism and essential hypertension in Serbian population. Clin Chim Acta 327: 181-185. [Crossref]

16. Kobashi G, Hata A, Ohta K, Yamada H, Kato EH, et al. (2004) A1166C variant of angiotensin II type 1 receptor gene is associated with severe hypertension in pregnancy independently of T235 variant of angiotensinogen gene. J Hum Genet 49: 182-186. [Crossref]

17. Niu W, Qi Y, Hou S, Zhai X, Zhou W, et al. (2009) Haplotype-based association of the renin-angiotensin-aldosterone system genes polymorphisms with essential hypertension among Han Chinese: the Fangshan study. J Hypertens 27: 1384-1391. [Crossref]
18. Mehri S, Mahjoub S, Hammami S, Zaroui A, Frih A, et al. (2012) Renin-angiotensin system polymorphisms in relation to hypertension status and obesity in a Tunisian population. Mol Biol Rep 39: 4059-4065. [Crossref]

19. Schmidt S, Beige J, Walla-Friedel M, Michel MC, Sharma AM, et al. (1997) A polymorphism in the gene for the angiotensin II type 1 receptor is not associated with hypertension. J Hypertens 15: 1385-1388. [Crossref]

20. Morisawa T, Kishimoto Y, Kitano M, Kawasaki H, Hasegawa J (2001) Influence of angiotensin II type 1 receptor polymorphism on hypertension in patients with hypercholesterolemia. Clin Chim Acta 304: 91-97. [Crossref]

21. Takami S, Katsuya T, Rakugi H, Sato N, Nakata Y, et al. (1998) Angiotensin II type 1 receptor gene polymorphism is associated with increase of left ventricular mass but not with hypertension. Am J Hypertens 11: 316-321. [Crossref]

22. Bautista LE, Vargas CI, Oróstegui M, Gamarra G (2008) Population-based casecontrol study of renin-angiotensin system genes polymorphisms and hypertension among Hispanics. Hypertens Res 31: 401-408. [Crossref]

Copyright: $\odot 2015$ Shamaa MM. This is an open-access article distributed under the terms of the Creative Commons Attribution License, which permits unrestricted use, distribution, and reproduction in any medium, provided the original author and source are credited. 